\title{
Soil Chemical Characterization and Fertility Status in Selected Irrigation Schemes in Unguja and Pemba Isles, Zanzibar
}

\author{
Halima Mmbaga ${ }^{1, ~ *, ~ J o a c h i m ~ H J R ~ M a k o i ~}{ }^{2}$ \\ ${ }^{1}$ Morogoro Zonal Irrigation Office, National Irrigation Commission, Morogoro, Tanzania \\ ${ }^{2}$ Freelance Consultant, Moshi, Tanzania
}

Email address:

mbagahalima1@gmail.com (H. Mmbaga)

${ }^{*}$ Corresponding author

\section{To cite this article:}

Halima Mmbaga, Joachim HJR Makoi. Soil Chemical Characterization and Fertility Status in Selected Irrigation Schemes in Unguja and Pemba Isles, Zanzibar. International Journal of Applied Agricultural Sciences. Vol. 4, No. 3, 2018, pp. 60-70.

doi: 10.11648/j.ijaas.20180403.12

Received: June 8, 2018; Accepted: June 27, 2018; Published: July 30, 2018

\begin{abstract}
A survey was undertaken to assess the soil chemical properties and fertility status in selected irrigation schemes in Unguja and Pemba Isles in October, 2017 during the short rainy seasons. These schemes include Dobi, Kwalempona, Machigini and Ole in Pemba and Bandamaji, Kibonde Mzungu, Koani, Mchangani and Mtwango in Unguja. Soil sampling was done after the soils were grouped into similar pedons following pedogeomorphic approach whereby fifteen and ten mapping units were delineated in Pemba and Unguja respectively. Using zigzag sampling techniques, nineteen composite samples were collected in quadruplicate at a depth of $0-30 \mathrm{~cm}$ from the delineated pedogeomorphic units at a radius of $20 \mathrm{~m}$ around the soil pits. Soil samples were bulked, thoroughly mixed, sub sampled to obtain a representative sample, packed and sent to NSS laboratory for analysis. The results showed significant difference in fertility status in the selected irrigation schemes. The $\mathrm{pH}$ was rated as neutral to strongly acid and or very strongly acid. Of the 25 surveyed mapping units (MUs), $47 \%$ were rated as medium acid, $26 \%$ as strongly acid, $11 \%$ as slightly acid and neutral and $5 \%$ as very strongly acid. Per cent OC was high in $21 \%$, medium in $63 \%$ and low in $16 \%$. In Machigini irrigation scheme, a third of the MUs was rated as having high \% OC compared with the two thirds with medium values. Nitrogen was very low in $89 \%$ and low in $11 \%$ of the surveyed MUs. Whereas that all the surveyed MUs had $\mathrm{N}$ below the threshold value $\left(<2 \mathrm{~g} \mathrm{~kg}^{-1}\right), 84 \%$ had low $\mathrm{P}$ and $16 \%$ has medium levels of available P. CEC values were rated as medium in $32 \%$, high in $16 \%$ and very high in $53 \%$ of the MUs surveyed. The C:N ratio suggested that SOM was of poor quality in $89 \%$ and moderate in $11 \%$ of MUs and all the MUs had C/N ratio outside the suggested range. Nutrient balance shows that $\mathrm{Ca} / \mathrm{Mg}$ ratio in $58 \%$ of the MUs was optimal for most crops and $42 \%$ was non-optimal. In conclusion, the soil fertility status and overall information from this study could be used in project irrigation design and fertilizer management studies to establish nutrient and drainage requirements for rice and other crops grown in these areas.
\end{abstract}

Keywords: Calcium, Cation Exchange Capacity, Fertility Constraints

\section{Introduction}

Agriculture is by far the most important source of employment and a base for foreign exchange earnings in Pemba and Unguja isles. On average, $70 \%$ of the population depends directly or indirectly in the agriculture sector for their livelihood [1]. By implication the sector has high potential for addressing high levels of income poverty, food insecurity and other socio-economic challenges. As a result, the sector deserves adequate public and private sector investment for attaining and maintaining the anticipated high growth rate. However, agricultural production in Unguja and Pemba is small scale, predominantly subsistence and largely rainfed. Unfortunately, rainfall in these areas is too erratic and unreliable for dry season farming, making supplementary irrigation necessary for successful crop growth and 
development. Globally, smallholder irrigation systems are viewed as critical for increasing crop water supply and sustained livelihoods in semi-arid regions [2]. Improving agriculture and enhancing productivity through smallholder irrigation is therefore one of the ways for alleviating poverty and improving the livelihoods of rural communities [3]. This is particularly true for Pemba and Unguja Isles where some irrigation schemes have been selected for development under Expanding Rice Production Project (ERPP). It is believed that with irrigation improvement and development, more area will be put under cultivation particularly during the dry season and reach the full irrigation potential of the districts in which the selected irrigation schemes are situated. Reliable availability of crop water requirement through irrigation water during growth of various crops including paddy will contribute significantly to the economic growth, not only for the people within the selected irrigation schemes in Pemba and Unguja Isles, but also will contribute to the overall National Economic Growth. The most commonly grown crops in these schemes are: maize (Zea mays L.), rice (Oryza sativa L.), beans (Phaseolus vulgaris L) and cowpea (Vigna unguiculata L.). Although these crops are commonly grown in the study area, farmers in the selected irrigation schemes have shown interest in paddy cultivation with a view to address food security and economic challenges if irrigation water availability is ensured. As it is well known that irrigation development is an expensive undertaking, detailed feasibility study is mandatory including the fertility status of the areas to be developed for irrigation. This is because nutrients and nutrients balance is of great challenge in most areas of the district just as in similar environments in the tropics $[4,5]$. Common soil fertility challenges in most areas in the tropics include excessive leaching, chemical degradation, nutrient mining and salinity, decline in soil organic matter and high prices of fertilizers $[4,6,7]$.

Due to these challenges and other complex soil, crop management, farming systems and soil fertility [8] the average yield of paddy in the study area is $0.4 \mathrm{t} \mathrm{ha}^{-1}$ which is very low compared with a potential of $8 \mathrm{t} \mathrm{ha}^{-1}$ reported elsewhere $[4,9,10]$. Although no studies have been conducted on the assessment of soil chemical properties and fertility in the selected irrigation schemes in Pemba and Unguja Isles irrigation development, experience from studies of similar environments elsewhere in Africa have shown soil fertility decline $[7,11,12,13]$ often leading to low crop production and productivity $[14,15,16,17]$ as may be the case with soils in the ERPP selected irrigation schemes in Pemba and Unguja Isles. Therefore, assessment of soil chemical properties and fertility status in the study areas was necessary and was assessed based on standard key indicators as reported in $[18,19]$ as are realistic in predicting plant growth and development. Assessment and understanding of the soil fertility status based on the attributes described in Monreal et al. [18] and Brady and Weil [19] will not only enhance strategies for soil fertility management and land development, but also will provide input into the design and planning irrigation infrastructures and crop nutrition packages in the study areas. To date, studies on soil fertility status in Pemba and Unguja Isles are very scarce [5, 13, 20]. The objective of this study was therefore to assess the soil chemical properties and fertility status in the selected ERPP irrigation schemes of Pemba and Unguja Isles.

\section{Material and Methods}

\subsection{Description of Study Area}

Machigini, Dobi, Ole and Kwalempona Irrigation schemes are located in Pemba which is divided into Pemba North and South. Machigini is located in Mkoani, Dobi and Ole are located in Chakechake in Pemba South, and Kwalempona is located in Wete, that is, in Pemba North. Bandamaji in Kaskazin A (Kaskazin), Koani and Mchangani in Central district (Unguja South), Mtwango and Kibonde mzungu in Magharib B (Unguja West).

The project areas receive seasonal rainfall ranging from $1,553 \mathrm{~mm}$ in Pemba Airport - 1,926 mm annum ${ }^{-1}$ in Wete, Pemba. Figures. 1 and 2 shows water balance and the determination of the growing period for the selected schemes at Kizimbani and Zanzibar Airport on one hand and Pemba Airport, Wete Pemba and Matangatuani stations on the other hand. Average yearly rainfall amounts to about $1,769 \mathrm{~mm}$ per annum as compared to $1,449 \mathrm{~mm}$ as annual evapotranspiration. The rainfall pattern is characteristically bi-modal with two rain seasons separated by dry season (Figures 1 and 2). Short rains (Vuli) begin October and end in December while long rains (Masika) usually start in March and ends in May. In Pemba survey areas, Masika rains comprise of an average of $57 \%$ of the total rains compared with Vuli which comprise of $22 \%$ of the total rains. Similarly, Masika rains in Unguja surveyed areas comprise of an average of $50 \%$ compared with Vuli which comprise of $29 \%$ of the total rains. Some of the study areas experiences seasonal flooding on the most of the valleys in some years. Farmers in most of the surveyed irrigation schemes in both Pemba and Unguja do not practice irrigation at all. Lack of irrigation and drainage infrastructure is probably the main cause for this problem. 


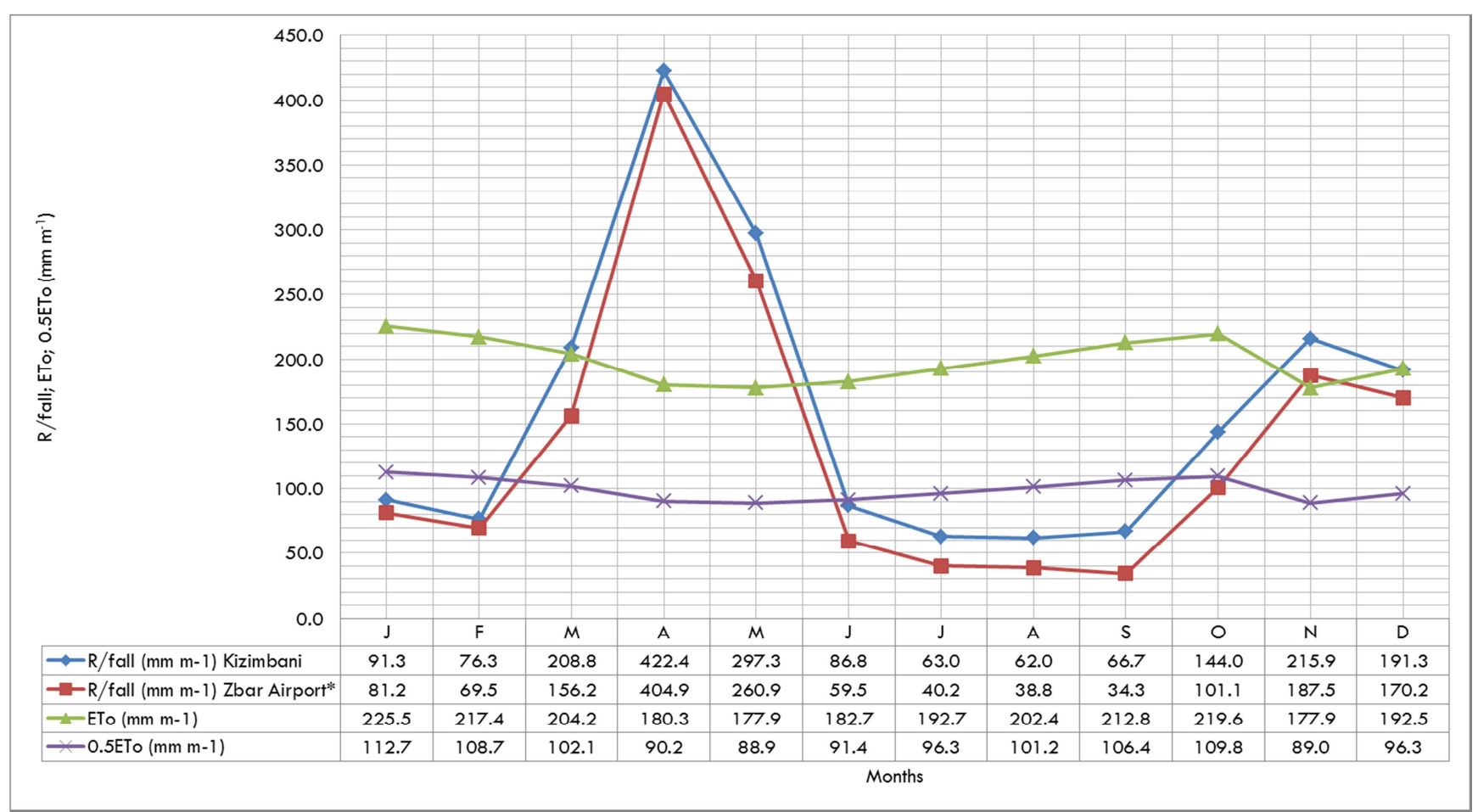

Figure 1. Water balance and the determination of the growing period for the selected schemes.

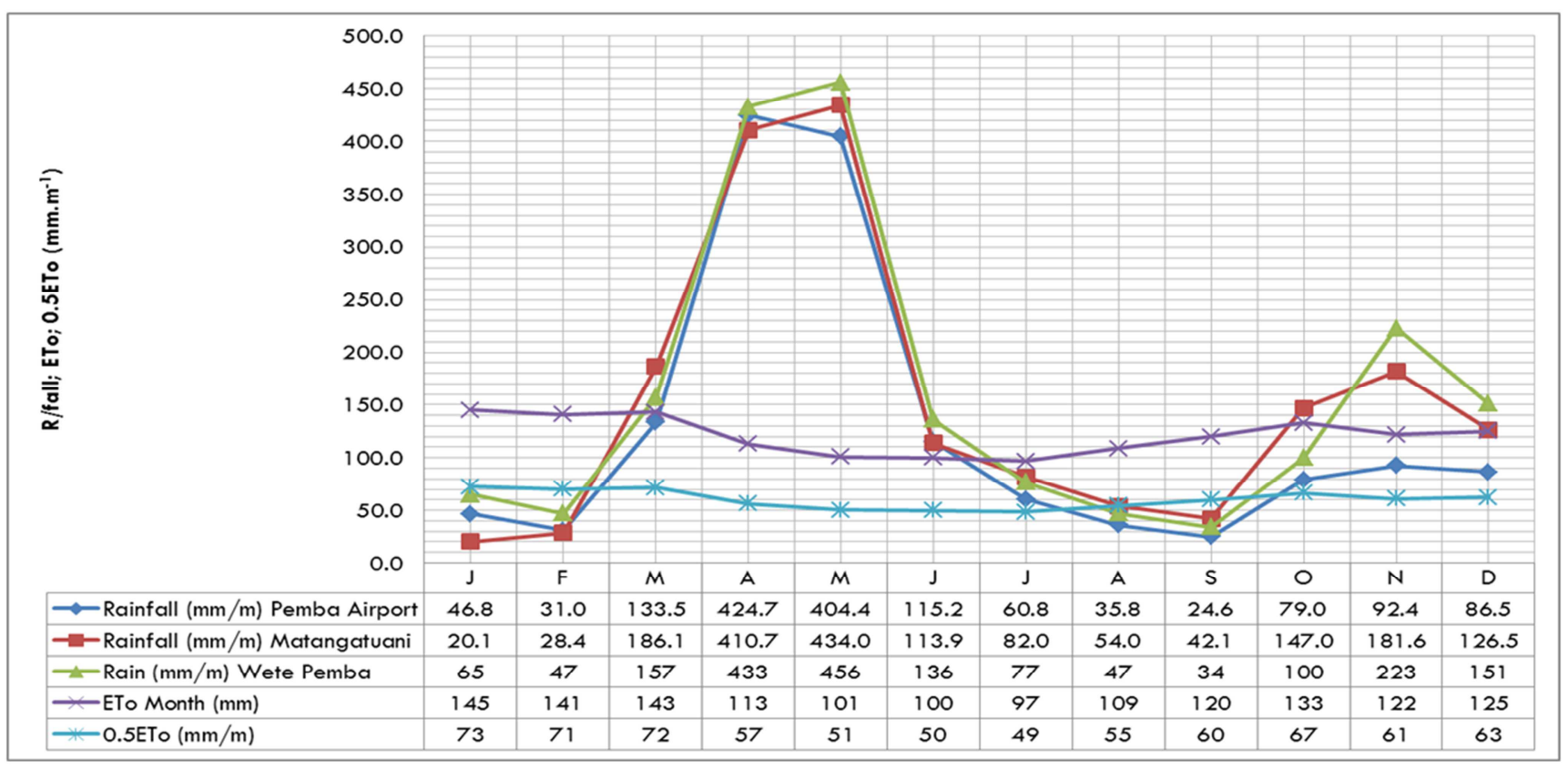

Figure 2. Water balance and the determination of the growing period for the ERPP irrigation schemes in Unguja Island (Note: Rainfall for Zanzibar Airport was an average of data obtained from Zanzibar Airport and Kisauni: Latitude $613^{\prime} S$, altitude $18 m$ as they seem to be nearby).

The climate variables representative of the study areas in Pemba and Unguja are presented in Table 1. In Pemba, the mean temperature varies from $26.6^{\circ} \mathrm{C}$ in July/August to $29.6^{\circ} \mathrm{C}$ in February. The monthly average relative humidity (RH) varies from $75 \%$ (i.e. July/August) to $83.0 \%$ (i.e. April and November). The potential evaporation is about $1,449 \mathrm{~mm}$ per annum and varies widely throughout the year from 97 to
$145.0 \mathrm{~mm}$ per month in July and January respectively. In Unguja, the mean temperature varies from $24.9^{\circ} \mathrm{C}$ in September to $28.4^{\circ} \mathrm{C}$ in February. The monthly average relative humidity (RH) varies from $78 \%$ in August to $86.0 \%$ in April. The potential evaporation is about 2,386 mm per annum and varies widely throughout the year from 177.9 to $225.5 \mathrm{~mm} \mathrm{month}^{-1}$ in May and January respectively. 
Table 1. Climatic data representative for Pemba and Unguja selected ERPP irrigation schemes.

\begin{tabular}{|c|c|c|c|c|c|c|c|c|c|c|c|c|c|}
\hline Climate Variable & $\mathbf{J}$ & $\mathbf{F}$ & $\mathbf{M}$ & $\mathbf{A}$ & $\mathbf{M}$ & $\mathbf{J}$ & $\mathbf{J}$ & $\mathbf{A}$ & $\mathbf{S}$ & $\mathbf{O}$ & $\mathbf{N}$ & D & Total \\
\hline \multicolumn{14}{|l|}{ PEMBA } \\
\hline Rain (mm) Wete & 65.0 & 47.0 & 157.0 & 433.0 & 456.0 & 136.0 & 77.0 & 47.0 & 34.0 & 100.0 & 223.0 & 151.0 & $1,926.0$ \\
\hline Rainfall $(\mathrm{mm} / \mathrm{m})$ PBA Airport & 46.8 & 31.0 & 133.5 & 424.7 & 404.4 & 115.2 & 60.8 & 35.8 & 24.6 & 79.0 & 92.4 & 86.5 & $1,553.1$ \\
\hline Rainfall (mm/m) Matangatuani & 20.1 & 28.4 & 186.1 & 410.7 & 434.0 & 113.9 & 82.0 & 54.0 & 42.1 & 147.0 & 181.6 & 126.5 & $1,826.6$ \\
\hline Mean Min Temp $\left({ }^{\circ} \mathrm{C}\right)$ & 25.3 & 25.1 & 25.4 & 25.3 & 24.7 & 24.3 & 23.6 & 23.5 & 23.4 & 23.9 & 24.6 & 25.2 & \\
\hline Mean Max Temp $\left({ }^{\circ} \mathrm{C}\right)$ & 33.4 & 34.0 & 33.5 & 32.5 & 31.4 & 30.3 & 29.6 & 29.7 & 30.7 & 31.5 & 32.6 & 33.4 & \\
\hline Mean Temp $\left({ }^{\circ} \mathrm{C}\right)$ & 29.4 & 29.6 & 29.5 & 28.9 & 28.1 & 27.3 & 26.6 & 26.6 & 27.1 & 27.7 & 28.6 & 29.3 & \\
\hline Mean RH (\%) & 78.0 & 76.0 & 81.0 & 83.0 & 81.0 & 76.0 & 75.0 & 75.0 & 76.0 & 77.0 & 83.0 & 81.0 & \\
\hline Sunshine (\%) & 45 & 35 & 50 & 40 & 35 & 35 & 33 & 35 & 40 & 45 & 40 & 40 & \\
\hline Day length (h) & 12.4 & 12.3 & 12.1 & 12 & 11.9 & 11.8 & 11.8 & 11.9 & 12.1 & 12.2 & 12.3 & 12.4 & \\
\hline PET Daily (mm) & 4.7 & 5.0 & 4.6 & 3.3 & 3.3 & 3.3 & 3.1 & 3.5 & 4.0 & 4.3 & 4.1 & 4.1 & \\
\hline PET Month (mm) & 145 & 141 & 143 & 113 & 101 & 100 & 97 & 109 & 120 & 133 & 122 & 125 & $1,449.0$ \\
\hline 0.5 PET $(\mathrm{mm} / \mathrm{m})$ & 73 & 71 & 72 & 57 & 51 & 50 & 49 & 55 & 60 & 67 & 61 & 63 & 724.5 \\
\hline Wind $(\mathrm{m} / \mathrm{s})$ & 1.7 & 1.4 & 1.0 & 1.0 & 1.1 & 1.6 & 1.2 & 1.3 & 1.4 & 1.5 & 1.3 & 1.2 & \\
\hline \multicolumn{14}{|l|}{ UNGUJA } \\
\hline Rainfall (mm/m) ZNZ Airport & 91.3 & 76.3 & 208.8 & 422.4 & 297.3 & 86.8 & 63.0 & 62.0 & 66.7 & 144.0 & 215.9 & 191.3 & 1,926 \\
\hline Rainfall (mm/m) Kizimbani & 81.2 & 69.5 & 156.2 & 404.9 & 260.9 & 59.5 & 40.2 & 38.8 & 34.3 & 101.1 & 187.5 & 170.2 & 1,604 \\
\hline Mean min Temp $\left({ }^{\circ} \mathrm{C}\right)$ & 24.1 & 23.8 & 24.1 & 24.2 & 23.4 & 22.5 & 21.5 & 20.6 & 20.4 & 21.5 & 22.6 & 23.6 & \\
\hline Mean Max Temp $\left({ }^{\circ} \mathrm{C}\right)$ & 32.4 & 32.9 & 32.1 & 30.4 & 29.5 & 29.1 & 28.7 & 29.2 & 30.3 & 31.1 & 30.8 & 30.3 & \\
\hline Mean MeanTemp $\left({ }^{\circ} \mathrm{C}\right)$ & 28.2 & 28.4 & 28.1 & 27.3 & 26.5 & 25.8 & 25.1 & 24.9 & 25.4 & 26.3 & 26.7 & 27.0 & \\
\hline Mean RH (\%) & 79 & 79 & 83 & 86 & 84 & 81 & 79 & 78 & 79 & 80 & 85 & 84 & \\
\hline Sunshine (\%) & 60.0 & 65.0 & 60.0 & 48.0 & 59.0 & 63.0 & 61.0 & 71.0 & 70.0 & 67.0 & 60.0 & 64.0 & \\
\hline Day length (h) & 12.4 & 12.3 & 12.1 & 12.0 & 11.8 & 11.7 & 11.8 & 11.9 & 12.1 & 12.2 & 12.4 & 12.5 & \\
\hline PET Daily (mm) & 5.5 & 5.8 & 5.3 & 4.4 & 4.6 & 4.6 & 4.6 & 5.1 & 5.5 & 5.5 & 5.0 & 5.4 & \\
\hline ETo (mm/month) & 225.5 & 217.4 & 204.2 & 180.3 & 177.9 & 182.7 & 192.7 & 202.4 & 212.8 & 219.6 & 177.9 & 192.5 & 2,386 \\
\hline $0.5 \mathrm{ETo}(\mathrm{mm} / \mathrm{m})$ & 112.7 & 108.7 & 102.1 & 90.2 & 88.9 & 91.4 & 96.3 & 101.2 & 106.4 & 109.8 & 89.0 & 96.3 & 1,193 \\
\hline Wind $(\mathrm{m} / \mathrm{s})$ & 1.9 & 1.8 & 1.8 & 1.6 & 2.2 & 2.3 & 2.3 & 2.2 & 2.2 & 2.0 & 1.6 & 2.0 & \\
\hline
\end{tabular}

Source: Tanzania Meteorological Agency: Rainfall Data (mm) for Pemba Airport (1984 - 2012); Matangatuani (2001-2012); Temp data (1994 - 2012) from Pemba Station, Wete (Latitude 5 04'S, altitude 20 m); TMA Zanzibar RH (1990 - 2013); Rainfall; Temperature and Evaporation (1984 - 2013). Total annual rainfall $\approx 1769 \mathrm{~mm}$, Total annual Evaporation $(\mathrm{Pan}) \approx 1,087 \mathrm{~mm}$ (Pemba) and 1,765 $\mathrm{mm} \mathrm{m}^{-1}$ Rainfall in Unguja and ETo of 1,789 $\mathrm{mm} \mathrm{m}^{-1}$.

\subsection{Soil Sampling}

Soil sampling in the ERPP selected irrigation schemes in Pemba and Unguja was done after the soils were grouped into similar soil types or pedons following pedogeomorphic approach [21] whereby a total of twenty five (25) mapping units were delineated. Of the total (25) mapping units, fifteen (15) were from Pemba irrigation schemes and ten (10) from Unguja irrigation schemes. Using zigzag sampling techniques, nineteen (19) disturbed soil samples were then collected at depth $0-30 \mathrm{~cm}$ from the delineated pedogeomorphic units. Soil samples from each soil type were bulked, thoroughly mixed, sub sampled to obtain a representative composite sample. After the soil samples were filled in plastic bags and labelled, they were sent for laboratory analysis at the National Soil Service laboratory, Mlingano (NSS), Tanga, Tanzania. In the laboratory, the samples were air dried and then ground to pass through a 2$\mathrm{mm}$ sieve for determination of physical chemical fertility indicators. These disturbed samples were divided into four (4) sub-samples to obtain four (4) replicates after which they were analysed separately.

\subsection{Soil Physicochemical Indicators}

Particle size analysis was determined by Bouyoucos hydrometer method after dispersion with $5 \%$ sodium hexametaphosphate [22] and textural classes were determined using the USDA textural class triangle [23]. Organic carbon was determined by the Walkley and Black wet oxidation method [24] and OC was converted to organic matter (OM) by multiplying by a factor of 1.724 [25]. Soil reaction was measured potentiometrically in water and $1 \mathrm{~N}$ $\mathrm{KCl}$ at a ratio of 1: 2.5 soils: water and $\mathrm{KCl}$ [26]. Total nitrogen was determined using micro-Kjeldahl digestion distillation method [27].

Determination of $\mathrm{Ca}, \mathrm{Mg}, \mathrm{K}, \mathrm{Na}$ referred to as exchangeable bases and CEC referred to as cation exchange capacity depended on soil reaction. In soils with $\mathrm{pH}<7.5$, were extracted by saturating soils with $1 \mathrm{M}$ ammonium acetate $\left(\mathrm{NH}_{4} \mathrm{OAc}\right)$ at $\mathrm{pH} 7$, ethanol and acidified $1 \mathrm{MKCl}$ in the first percolate [28]. The absorbed $\mathrm{NH}_{4}{ }^{+}$displaced by $\mathrm{K}^{+}$ using $1 \mathrm{M} \mathrm{KCl}$ was then determined by Kjeldahl distillation method for the estimation of CEC of the soil. For soils with $\mathrm{pH}>7.5$ and high carbonates contents, the method recommended by [29] was followed. Determination of K and $\mathrm{Na}$ was done with flame photometer, $\mathrm{Ca}$ and $\mathrm{Mg}$ by Inductively Coupled Plasma Atomic Absorption Emission Spectrophotometer [30]. Cation exchange capacity (CEC) was done following the method by [30]. Potentiometric method was used to determine electrical conductivity (EC) of 
soil samples following the procedure described by [31]. The total exchangeable bases (TEB) were calculated arithmetically as a sum of the four exchangeable bases $\left(\mathrm{Ca}^{2+}\right.$, $\mathrm{Mg}^{2+}, \mathrm{Na}^{+}$and $\mathrm{K}^{+}$) for a given soil sample. Available $\mathrm{P}$ was extracted spectrophotometrically [32] by reacting with ammonium molybdate using ascorbic acid as a reductant in the presence of antimony as in [33]. The total exchangeable bases (TEB) were obtained as the sum of exchangeable $\mathrm{Ca}$, $\mathrm{Mg}, \mathrm{K}$ and Na. Per cent base saturation (\% BS) was obtained by dividing TEB by CEC and then multiplied by 100 [34]. Exchangeable sodium percentage (ESP) was obtained by dividing total exchangeable sodium by $\mathrm{CEC}$, and then multiplied by 100 . The K:TEB was obtained by dividing $\mathrm{K}$ by TEB.

\subsection{Statistical Analysis}

One-way ANOVA was used to compare soil mineral elements from the different pedogeomorphic units. The analysis was performed using the STATISTICA software of 2016 version (Stat Soft Inc., Tulsa, OK, USA) [35]. The mean values were compared at 5\% level of significance using least significant differences (L. S. D) test.

\section{Results and Discussion}

\subsection{Soil Reaction}

Results of the chemical properties of the top soils in the ERPP irrigation schemes in both Pemba and Unguja Islands are summarized in Tables 2, 3 and 4. The data shows that the
$\mathrm{pH}$ of top soils ranged from 5.1 to 6.9 in Pemba and 5.0 to 6.8 in Unguja. These were rated as neutral $(\mathrm{N})$ to strongly acid (SA) and or very strongly acid (VSA) [36]. Of the 25 surveyed mapping units, $47 \%$ were rated as medium acid (i.e. $\mathrm{pH}: 5.6-6.0$ ), 26\% were strongly acid (i.e. $\mathrm{pH}: 5.6-6.0$ ), $11 \%$ were slightly acid (i.e. pH: $6.1-6.5$ ) and neutral (i.e. pH: $6.6-7.3$ ), and $5 \%$ were very strongly acid (i.e. $\mathrm{pH}$ : $4.5-$ 5.0) as observed in Mchangani irrigation scheme. The nature of the observed acidity in the majority of these soils threatens the availability of mineral elements such as $\mathrm{P}$ which is readily available in soils with $\mathrm{pH}$ at 6.5 . The very strongly acid observed in $5 \%$ of the mapping units can lead to high concentrations of soluble $\mathrm{Al}, \mathrm{Fe}$ and $\mathrm{Mn}$. Consequently, high levels of these mineral elements may be toxic to the growth of sensitive plants due to Al toxicity $[37 ; 38]$. Soils tend to become acidic or strongly acid as a result of (1) leached basic ions $(\mathrm{Ca}, \mathrm{Mg}, \mathrm{K}$ and $\mathrm{Na}$ ); (2) formation of a weak organic acid as a result of dissolved $\mathrm{CO}_{2}$ from decomposing $\mathrm{OM}$ and root respiration; (3) formation of strong organic and inorganic acids, such as nitric $\left(\mathrm{HNO}_{3}\right)$ and sulphuric $\left(\mathrm{H}_{2} \mathrm{SO}_{4}\right)$ acids from decaying $\mathrm{OM}$ and oxidation of ammonium $\left(\mathrm{NH}_{3}\right)$ and sulphur (S) fertilizers. However, most plant mineral elements are available in the $\mathrm{pH}$ range of approximately $6.5-$ 7.0 [39]. Similarly, soil $\mathrm{pH}$ can influence plant growth by its effect on the activity of beneficial micro-organisms. For example, bacteria that decompose SOM are hindered in strong acid soils which in turn prevent OM from breaking down. As a result, OM is accumulated un-decomposed or unbroken, consequently tying up of nutrients such as $\mathrm{N}$ making them unavailable to plants.

Table 2. Soil fertility data for the selected ERPP Irrigation schemes in Pemba Island (topsoil samples 0 - $30 \mathrm{~cm}$ depth).

\begin{tabular}{|c|c|c|c|c|c|c|}
\hline \multirow{2}{*}{ MU } & \multirow{2}{*}{ Texture } & \multirow{2}{*}{$\frac{\mathrm{pH}}{\left(\mathrm{H}_{2} \mathrm{O}\right)}$} & \multirow{2}{*}{$\begin{array}{l}\text { EC } \\
d S . m^{-1}\end{array}$} & \multirow{2}{*}{$\begin{array}{l}\text { OC } \\
\text { g.kg }\end{array}$} & \multirow[t]{2}{*}{ OM } & \multirow[t]{2}{*}{ TN } \\
\hline & & & & & & \\
\hline \multicolumn{7}{|l|}{ PEMBA } \\
\hline \multicolumn{7}{|c|}{ Dobi Irrigation Scheme } \\
\hline DO-Val & SCL & $6.3 \mathrm{a}$ & $0.05 b$ & $10.8 \mathrm{~b}$ & $18.5 b$ & $0.2 \mathrm{c}$ \\
\hline DO-Va2 & $\mathrm{SC}$ & $5.7 \mathrm{~b}$ & $0.06 \mathrm{a}$ & $11.0 \mathrm{~b}$ & $18.9 \mathrm{~b}$ & $0.7 \mathrm{a}$ \\
\hline DO-Hil & SCL & $5.4 \mathrm{c}$ & $0.06 \mathrm{a}$ & $11.6 \mathrm{a}$ & $19.9 \mathrm{a}$ & $0.4 \mathrm{~b}$ \\
\hline \multicolumn{7}{|c|}{ One Way ANOVA (F-Statistics) } \\
\hline CV $(\%)$ & & 5 & 0 & 7 & 9 & 1 \\
\hline \multicolumn{7}{|c|}{ Kwalempona Irrigation Scheme } \\
\hline KWA-Val & $\mathrm{C}$ & $6.0 \mathrm{~b}$ & $0.08 \mathrm{~b}$ & $21.2 \mathrm{a}$ & $36.4 \mathrm{a}$ & $0.6 \mathrm{a}$ \\
\hline KWA-Va2 & $\mathrm{C}$ & $6.9 \mathrm{a}$ & $0.12 \mathrm{a}$ & $16.0 \mathrm{~b}$ & $27.4 \mathrm{~b}$ & $0.5 \mathrm{~b}$ \\
\hline KWA-Hil & SCL & $5.9 \mathrm{~b}$ & $0.04 \mathrm{c}$ & $16.3 b$ & $28.1 \mathrm{~b}$ & $0.6 \mathrm{a}$ \\
\hline \multicolumn{7}{|c|}{ One Way ANOVA (F-Statistics) } \\
\hline Rep & & $57.6 * * *$ & $1607.1 * * *$ & $197.5^{* * *}$ & $196.8 * * *$ & $77.3 * * *$ \\
\hline \multicolumn{7}{|c|}{ Kwalempona Irrigation Scheme } \\
\hline MA-Va1 & $\mathrm{C}$ & $5.1 \mathrm{~b}$ & $0.11 \mathrm{c}$ & $19.7 b$ & $33.9 b$ & $0.7 \mathrm{~b}$ \\
\hline MA-Va2 & SCL & $5.7 \mathrm{a}$ & $0.03 b$ & $20.5 b$ & $35.3 b$ & $0.8 \mathrm{a}$ \\
\hline MA-Hil & SCL & $5.1 \mathrm{~b}$ & $0.06 \mathrm{a}$ & $25.9 \mathrm{a}$ & $44.6 \mathrm{a}$ & $0.8 \mathrm{a}$ \\
\hline \multicolumn{7}{|c|}{ One Way ANOVA (F-Statistics) } \\
\hline Rep & & $31.9 * * *$ & $2213.9 * * *$ & $173.0 * * *$ & $173.6 * * *$ & $42.4 * * *$ \\
\hline $\mathrm{CV}(\%)$ & & 5 & 1 & 9 & 12 & 2 \\
\hline \multicolumn{7}{|c|}{ OLE Irrigation Scheme } \\
\hline OLE-Pa1 & $\mathrm{C}$ & $5.9 \mathrm{a}$ & $0.02 b$ & $16.1 \mathrm{~b}$ & $27.7 b$ & $0.7 \mathrm{~b}$ \\
\hline OLE-Pa2 & $\mathrm{SCL}$ & $5.4 \mathrm{~b}$ & $0.26 \mathrm{a}$ & $24.9 \mathrm{a}$ & $42.8 \mathrm{a}$ & $0.8 \mathrm{a}$ \\
\hline \multicolumn{7}{|c|}{ One Way ANOVA (F-Statistics) } \\
\hline Rep & & $29.31 * *$ & $6352.941 * * *$ & $660.59 * * *$ & $657.94 * * *$ & $66.37 * *$ \\
\hline CV $(\%)$ & & 5 & 1 & 9 & 12 & 2 \\
\hline
\end{tabular}


Table 2. Continued.

\begin{tabular}{|c|c|c|c|c|c|c|c|c|c|c|}
\hline \multirow{2}{*}{ MU } & \multirow{2}{*}{ Texture } & \multirow{2}{*}{$\mathbf{C} / \mathbf{N}$} & Pav & CEC & $\mathbf{C a}$ & Mg & $\mathbf{K}$ & $\mathbf{N a}$ & BS & ESP \\
\hline & & & mg.kg-1 & \multicolumn{5}{|c|}{$\left(\mathrm{cmol}(+) . \mathrm{kg}^{-1}\right)$} & \multicolumn{2}{|l|}{$(\%)$} \\
\hline \multicolumn{11}{|l|}{ PEMBA } \\
\hline \multicolumn{11}{|c|}{ Dobi Irrigation Scheme } \\
\hline DO-Va1 & SCL & $43.0 \mathrm{a}$ & $5.9 b$ & $20.7 \mathrm{c}$ & $7.4 \mathrm{~b}$ & $2.0 \mathrm{c}$ & $0.07 b$ & $0.47 b$ & $48.0 \mathrm{~b}$ & $2.3 b$ \\
\hline DO-Va2 & SC & $15.0 \mathrm{c}$ & $5.6 \mathrm{c}$ & $28.2 \mathrm{~b}$ & $11.2 \mathrm{a}$ & $2.2 \mathrm{~b}$ & $0.06 \mathrm{c}$ & $0.69 \mathrm{a}$ & $50.0 \mathrm{a}$ & $2.4 \mathrm{a}$ \\
\hline DO-Hi1 & SCL & $32.0 \mathrm{~b}$ & $6.6 \mathrm{a}$ & $29.4 \mathrm{a}$ & $6.4 \mathrm{c}$ & $2.6 \mathrm{a}$ & $0.19 \mathrm{a}$ & $0.31 \mathrm{c}$ & $33.0 \mathrm{c}$ & $1.1 \mathrm{c}$ \\
\hline \multicolumn{11}{|c|}{ One Way ANOVA (F-Statistics) } \\
\hline CV $(\%)$ & & 12 & 5 & 10 & 6 & 3 & 1 & 1 & 13 & 3 \\
\hline \multicolumn{11}{|c|}{ Kwalempona Irrigation Scheme } \\
\hline KWA-Va1 & $\mathrm{C}$ & $33.0 \mathrm{a}$ & $5.8 \mathrm{~b}$ & $57.5 \mathrm{a}$ & $24.6 \mathrm{a}$ & $3.3 \mathrm{a}$ & $0.17 \mathrm{a}$ & $0.60 \mathrm{a}$ & $50.0 \mathrm{a}$ & $1.0 \mathrm{c}$ \\
\hline KWA-Va2 & $\mathrm{C}$ & $31.0 \mathrm{~b}$ & $0.5 \mathrm{c}$ & $11.5 \mathrm{c}$ & $4.2 \mathrm{c}$ & $0.9 \mathrm{c}$ & $0.14 \mathrm{~b}$ & $0.38 \mathrm{~b}$ & $50.0 \mathrm{a}$ & $3.3 \mathrm{a}$ \\
\hline KWA-Hi1 & SCL & $28.0 \mathrm{c}$ & $6.2 \mathrm{a}$ & $23.4 \mathrm{~b}$ & $6.3 b$ & $2.2 \mathrm{~b}$ & $0.14 b$ & $0.32 \mathrm{c}$ & $38.0 \mathrm{~b}$ & $1.4 \mathrm{~b}$ \\
\hline \multicolumn{11}{|c|}{ One Way ANOVA (F-Statistics) } \\
\hline Rep & & $50.3 * * *$ & $3149.1 * * *$ & $3217.9 * * *$ & $4276.3^{* * *}$ & $1963.4 * * *$ & $99.1 * * *$ & $805.9^{* * *}$ & $167.6 * * *$ & $2453.1 * * *$ \\
\hline MA-Va1 & $\mathrm{C}$ & $27.0 \mathrm{~b}$ & $6.1 \mathrm{a}$ & $56.2 \mathrm{a}$ & $19.1 \mathrm{a}$ & $6.2 \mathrm{a}$ & $0.29 \mathrm{c}$ & $0.68 \mathrm{a}$ & $47.0 \mathrm{a}$ & $1.2 \mathrm{~b}$ \\
\hline MA-Va2 & SCL & $26.0 \mathrm{~b}$ & $0.3 \mathrm{c}$ & $21.6 \mathrm{c}$ & $5.4 \mathrm{c}$ & $2.0 \mathrm{c}$ & $0.33 b$ & $0.60 \mathrm{~b}$ & $38.0 \mathrm{c}$ & $2.8 \mathrm{a}$ \\
\hline MA-Hil & SCL & $34.0 \mathrm{a}$ & $2.8 \mathrm{~b}$ & $42.7 b$ & $12.5 b$ & $3.6 \mathrm{~b}$ & $0.50 \mathrm{a}$ & $0.38 \mathrm{c}$ & $40.0 \mathrm{~b}$ & $0.9 \mathrm{c}$ \\
\hline \multicolumn{11}{|c|}{ One Way ANOVA (F-Statistics) } \\
\hline Rep & & $166.9 * * *$ & $4218.5^{* * *}$ & $1255.9 * * *$ & $1919.6^{* * *}$ & $1824.9 * * *$ & $631.5^{* * *}$ & $561.7 * * *$ & $95.7 * * *$ & $2326.6 * * *$ \\
\hline CV $(\%)$ & & 11 & 4 & 13 & 8 & 4 & 1 & 2 & 13 & 3 \\
\hline \multicolumn{11}{|c|}{ OLE Irrigation Scheme } \\
\hline OLE-Pa1 & $\mathrm{C}$ & $23.0 \mathrm{~b}$ & $9.6 \mathrm{a}$ & $47.5 \mathrm{a}$ & $20.9 a$ & $2.4 \mathrm{a}$ & $0.44 \mathrm{a}$ & $0.37 \mathrm{a}$ & $51.0 \mathrm{a}$ & $0.8 \mathrm{a}$ \\
\hline OLE-Pa2 & SCL & $30 \mathrm{a}$ & $6.8 \mathrm{~b}$ & $41.6 b$ & $18.6 b$ & $1.9 \mathrm{~b}$ & $0.22 b$ & $0.33 b$ & $51.0 \mathrm{a}$ & $0.8 \mathrm{a}$ \\
\hline \multicolumn{11}{|c|}{ One Way ANOVA (F-Statistics) } \\
\hline Rep & & $257.17 * * *$ & $424.86^{* * *}$ & $65.48 * *$ & $50.69 * *$ & $200.11 * * *$ & $1500.00 * * *$ & $48.82 * *$ & $0.00 \mathrm{~ns}$ & $0.00 \mathrm{~ns}$ \\
\hline CV (\%) & & 10 & 6 & 13 & 9 & 3 & 1 & 1 & 14 & 2 \\
\hline
\end{tabular}

*: significant at $P=.05$; **: significant at $P=.01 ; * * *$ significant at $P=.001$; ns: not significantly different from each other; CV: Coefficient of variation. Values followed by dissimilar letters in the same column for each parameter are significantly different from each other at $P=.05$ according to Fischer Least significance difference (LSD). EC = Electrical Conductivity, $\mathrm{TN}=$ Total Nitrogen; $\mathrm{C} / \mathrm{N}=\mathrm{Carbon} / \mathrm{Nitrogen}$ ratio, Pav = Available Phosphorus; $\mathrm{K}=\mathrm{Potassium}$; $\mathrm{Ca}=$ Calcium; $\mathrm{Mg}=$ Magnesium; $\mathrm{Na}=$ Sodium, $\mathrm{OC}=$ Organic Carbon; $\mathrm{CEC}=$ Cation Exchange Capacity; BS $=\mathrm{Base}$ Saturation, ESP $=$ Exchangeable Sodium Percentage; SCL = Sand Clay Loam; CL = Clay Loam; C = Clay; CH: Chipogolo; MSAG: Msagali; Pa: Plain; Pi: Piedmont.

\subsection{Soil Organic Carbon (SOC) and Organic Matter (SOM)}

Results of organic carbon (OC) determination from the top soil $(0-30 \mathrm{~cm})$ samples in ERPP irrigation schemes in Pemba and Unguja Isles ranged from $10.8 \mathrm{~g} \mathrm{~kg}^{-1}$ to $33.4 \mathrm{~g} \mathrm{~kg}^{-}$ 1. This corresponds to $18.5 \mathrm{~g} \mathrm{~kg}^{-1}$ to $57.4 \mathrm{~g} \mathrm{~kg}^{-1} \mathrm{SOM}$ (Tables 2, 3 and 4). The data showed that \% OC was high in $21 \%$, medium in $63 \%$ and low in $16 \%$ of the mapping units surveyed. In Pemba, Dobi MUs showed lowest \% OC compared with Kwalempona and Ole irrigation schemes which had medium \% OC. In Machigini irrigation scheme a third of the MUs (MA-Hil) were rated as high \% OC compared with the two thirds with medium values (MA-Va1 \& Va2). Since SOM content was calculated from SOC [25], these parameters has similar trend. It is generally accepted that a threshold for SOM in most soils is $34 \mathrm{~g} \mathrm{~kg}^{-1}$ below which decline in soil quality is expected [40]. Whereas $58 \%$ of the MUs were below critical limits, $42 \%$ were above the proposed threshold limits, suggesting that no decline in soil quality for the respective mapping units in ERPP irrigation schemes in Pemba and Unguja Islands [41]. Determination of Organic carbon (OC) or Soil Organic Matter (SOM) in the soil is important because humidified OM molecules may react with mineral colloids and contribute to the stabilization of soil aggregates. While SOM favours water retention capacity and adsorption of fulvic and humic compounds by $\mathrm{Fe}^{2+}$ and $\mathrm{Al}^{3+}$ oxide, it also prevents their crystallization hence decreasing fixation power with regards to phosphates at unfavourable $\mathrm{pH}$ values. SOM provides much of the CEC, and, surface soils contain large quantity of plant nutrients with storehouse considered as slow release of nutrient especially so by $\mathrm{N}$.

\subsection{Total Nitrogen (TN)}

Inadequate amount of $\mathrm{N}$ in the soil is the primary factor that limits plant growth and development in many parts of the world [42; 43]. Nitrogen levels in the study areas were very low in $89 \%$ and low in $11 \%$ of the MUs surveyed with values ranging from $0.2-1.6 \mathrm{~g} \mathrm{~kg}^{-1}$. According to NSS [36] guidelines, the proposed threshold value for $\mathrm{N}$ in most crops in Tanzania is $2 \mathrm{~g}$ $\mathrm{kg}^{-1}$ soil. The results show that all the MUs surveyed for ERPP irrigation schemes in Pemba and Unguja Islands, had $\mathrm{N}$ below the threshold value $\left(<2 \mathrm{~g} \mathrm{~kg}^{-1}\right)$ (Tables 2 and 5). The observed very low or low $\mathrm{N}$ in the surveyed MUs may probably be due to low or medium SOM, low $\mathrm{pH}$ and low microbial activities in the soil [44; 41; Tables 2, 3 and 4]. So, any activity envisaged to improve the soil $\mathrm{pH}, \mathrm{SOM}$ quality as well as microbial activities can, consequently, lead to an increase in $\mathrm{N}$ in the soil [41]. The low to very low levels of $\mathrm{N}$ in the surveyed areas suggests 
application of ammoniocal form of $\mathrm{N}$, which resists better to leaching caused by rainfall or irrigation as the case may be in the

surveyed areas.

Table 3. Soil fertility data for the selected ERPP Irrigation schemes in Unguja Islands (topsoil samples $0-30 \mathrm{~cm}$ depth).

\begin{tabular}{|c|c|c|c|c|c|c|c|c|c|c|c|c|c|c|c|}
\hline \multicolumn{16}{|l|}{ UNGUJA } \\
\hline \multicolumn{16}{|c|}{ Bandamaji irrigation scheme } \\
\hline BM-Pa1 & $\mathrm{SC}$ & $6.8 \mathrm{a}$ & $0.13 \mathrm{a}$ & $20.1 \mathrm{a}$ & $34.6 \mathrm{a}$ & $0.9 \mathrm{a}$ & $24.0 \mathrm{c}$ & $6.1 \mathrm{a}$ & $15.4 \mathrm{~b}$ & $5.8 \mathrm{~b}$ & $1.2 \mathrm{~b}$ & $0.34 \mathrm{~b}$ & $0.39 \mathrm{c}$ & $50.0 \mathrm{~b}$ & $2.5 \mathrm{~b}$ \\
\hline BM-Pa2 & SCL & $5.9 \mathrm{c}$ & $0.07 \mathrm{c}$ & $18.3 \mathrm{~b}$ & $31.6 \mathrm{~b}$ & $0.4 \mathrm{c}$ & $49.0 \mathrm{a}$ & $3.0 \mathrm{~b}$ & $40.0 \mathrm{a}$ & $15.9 \mathrm{a}$ & $1.2 \mathrm{~b}$ & $0.10 \mathrm{c}$ & $1.08 \mathrm{a}$ & $46.0 \mathrm{c}$ & $2.7 \mathrm{a}$ \\
\hline BM-Pa3 & SCL & $6.2 \mathrm{~b}$ & $0.09 \mathrm{~b}$ & $13.7 \mathrm{c}$ & $23.5 \mathrm{c}$ & $0.5 \mathrm{~b}$ & $26.0 \mathrm{~b}$ & $0.7 \mathrm{c}$ & $41.2 \mathrm{a}$ & $15.6 \mathrm{a}$ & $4.8 \mathrm{a}$ & $0.44 \mathrm{a}$ & $0.58 \mathrm{~b}$ & $52.0 \mathrm{a}$ & $1.4 \mathrm{c}$ \\
\hline \multicolumn{16}{|c|}{ One Way ANOVA (F-Statistics) } \\
\hline Rep & & $\begin{array}{l}39.5^{* *} \\
*\end{array}$ & $702.3^{* * *}$ & $\begin{array}{l}264.5^{* *} \\
*\end{array}$ & $\begin{array}{l}270.0^{* *} \\
*\end{array}$ & $\begin{array}{l}1291.0^{*} \\
* *\end{array}$ & $\begin{array}{l}1188.8^{*} \\
* *\end{array}$ & $\begin{array}{l}3538.0 * \\
* *\end{array}$ & $\begin{array}{l}1349.8^{*} \\
* *\end{array}$ & $\begin{array}{l}1402.4^{*} \\
* *\end{array}$ & $\begin{array}{l}3750.0 * \\
* *\end{array}$ & $\begin{array}{l}2152.3 * * \\
*\end{array}$ & $\begin{array}{l}1727.1 * \\
* *\end{array}$ & $287^{* * *}$ & $\begin{array}{l}711.3 * * \\
*\end{array}$ \\
\hline CV (\%) & & 5 & 1 & 8 & 11 & 2 & 12 & 4 & 12 & 8 & 4 & 1 & 2 & 14 & 3 \\
\hline \multicolumn{16}{|c|}{ Mchangani Irrigation Scheme } \\
\hline MCH-Pa1 & $\mathrm{C}$ & $5.5 \mathrm{a}$ & $0.2 \mathrm{a}$ & $33.4 \mathrm{a}$ & $57.4 \mathrm{a}$ & $1.4 \mathrm{~b}$ & $24.0 \mathrm{a}$ & 7.1a & $23.5 \mathrm{~b}$ & $9.0 \mathrm{~b}$ & $1.4 \mathrm{~b}$ & $0.14 \mathrm{~b}$ & $0.6 \mathrm{a}$ & $48.0 \mathrm{a}$ & 2.6a \\
\hline MCH-Pa2 & SCL & $5.0 \mathrm{~b}$ & $0.1 \mathrm{~b}$ & $32.9 \mathrm{a}$ & $56.6 \mathrm{a}$ & $1.6 \mathrm{a}$ & $21.0 \mathrm{~b}$ & $6.2 \mathrm{~b}$ & $71.8 \mathrm{a}$ & $31.1 \mathrm{a}$ & $3.0 \mathrm{a}$ & $0.23 \mathrm{a}$ & $0.3 \mathrm{~b}$ & $48.0 \mathrm{a}$ & $0.4 \mathrm{~b}$ \\
\hline \multicolumn{16}{|c|}{ One Way ANOVA (F-Statistics) } \\
\hline Rep & & $33.9^{* *}$ & $\begin{array}{l}1500.0^{* *} \\
*\end{array}$ & $0.9 \mathrm{~ns}$ & $0.7 \mathrm{~ns}$ & $66.4^{* *}$ & $66.4 * *$ & $68.4 * *$ & $\begin{array}{l}3065.6^{*} \\
* *\end{array}$ & $\begin{array}{l}3494.6^{*} \\
* *\end{array}$ & $\begin{array}{l}1751.8^{*} \\
* *\end{array}$ & $837.9^{* * *}$ & $\begin{array}{l}1329.3^{*} \\
* *\end{array}$ & $0.00 \mathrm{~ns}$ & $\begin{array}{l}5245.7^{*} \\
* *\end{array}$ \\
\hline CV (\%) & & 5 & 1 & 12 & 15 & 2 & 10 & 5 & 15 & 10 & 3 & 1 & 1 & 14 & 3 \\
\hline
\end{tabular}

*: significant at $P=.05 ; * *$ : significant at $P=.01 ; * * *$ significant at $P=.001$; ns: not significantly different from each other; CV: Coefficient of variation. Values followed by dissimilar letters in the same column for each parameter are significantly different from each other at $P=.05$ according to Fischer Least significance difference $(\mathrm{LSD})$. $\mathrm{EC}=$ Electrical Conductivity, $\mathrm{TN}=$ Total Nitrogen; $\mathrm{C} / \mathrm{N}=$ Carbon/Nitrogen ratio, Pav = Available Phosphorus; $\mathrm{K}=$ Potassium; $\mathrm{Ca}=$ Calcium; $\mathrm{Mg}=$ Magnesium; $\mathrm{Na}=$ Sodium, $\mathrm{OC}=$ Organic Carbon $; \mathrm{CEC}=$ Cation Exchange Capacity; $\mathrm{BS}=$ Base Saturation, ESP $=$ Exchangeable Sodium Percentage; $\mathrm{SCL}=$ Sand Clay Loam; $\mathrm{CL}$ = Clay Loam; $\mathrm{C}$ = Clay; $\mathrm{CH}$ : Chipogolo; MSAG: Msagali; Pa: Plain; Pi: Piedmont.

\subsection{C/N Ratio}

As far as humification is concerned, an average $\mathrm{C} / \mathrm{N}$ ratio of 10 (i.e. 8 - 13) is considered as optimal [36]. The C: $\mathrm{N}$ ratio of most of the surveyed areas range from $15-49$ in ERPP irrigation schemes in Pemba and Unguja Islands (Table 2) and was rated as poor quality in $89 \%$ and moderate quality SOM in $11 \%$ of MUs (Table 4). It is generally accepted that $\mathrm{C} / \mathrm{N}$ ratios between 8 and 12 are considered to be the most favourable, implying a relatively fast mineralisation of $\mathrm{N}$ from the organic materials. Results show that all the mapping units had $\mathrm{C} / \mathrm{N}$ ratio outside the suggested range. The observed $\mathrm{C} / \mathrm{N}$ ratio in all the mapping units suggests suboptimal condition for plant growth. This calls for SOM management in all the irrigation schemes

\subsection{Available Phosphorus (AP)}

Phosphorus $(\mathrm{P})$ is an essential macro element for plant growth, hence an important soil fertility indicator. In agriculture, management of $\mathrm{P}$ is second only to management of $\mathrm{N}$ in its importance for the production of healthy and profitable crop yields. Results show that of all the top soil samples taken from the MUs in ERPP irrigation schemes in Pemba and Unguja Islands (Tables 2, 3 and 4), 84\% has low $\mathrm{P}$ and $16 \%$ has medium levels of available $\mathrm{P}$. The data showed that the available $\mathrm{P}$ range from $0.3-9.6 \mathrm{mg} \mathrm{kg}^{-1}$ top soils (Tables 2, 3). An average $P$ level of $7 \mathrm{mg} \mathrm{kg}^{-1}$ is considered optimal below which $\mathrm{P}$ deficiency symptoms are likely to occur in most crops. Based on the generally accepted threshold $\mathrm{P}$ level, $84 \%$ of the surveyed MUs has $\mathrm{P}$ values below the critical range and will need serious fertilizer management program. The medium $P$ availability manifested in $16 \%$ of all the mapping units in the areas suggests that $\mathrm{P}$ in these areas is moderately sufficient and may need frequent maintenance for sustainable irrigated agricultural development.

\subsection{Exchangeable Bases (K, $\mathrm{Mg}, \mathrm{Ca})$}

Results of the exchangeable bases $(\mathrm{Ca}, \mathrm{Mg}$ and $\mathrm{K}$ ) in the top soils of the MUs surveyed are presented in Tables 2, 3 and 4. These results indicate that whereas the levels of exchangeable $\mathrm{Ca}$ and $\mathrm{Mg}$ were generally medium or high to very high, $\mathrm{K}$ levels was rated as very low/low or medium

\subsubsection{Exchangeable Calcium}

Exchangeable $\mathrm{Ca}^{2+}$ in the topsoil of the ERPP irrigation schemes ranged from $4.2 \mathrm{cmol}(+) \mathrm{kg}^{-1}-31.1 \mathrm{cmol}(+) \mathrm{kg}^{-1}$ rated as high in $11 \%$ and very high in $89 \%$ of the MUs surveyed [45] proposed that in most of the crops, the recommended threshold level of $\mathrm{Ca}^{2+}$ is $5 \mathrm{cmol}(+) \mathrm{kg}^{-1}$. It is generally acknowledged that field conditions that limit $\mathrm{Ca}^{2+}$ uptake produce lower crop yields than crops grown with adequate $\mathrm{Ca}^{2+}$ [46]. Based on the critical limits, with the exception of KWA-Va2 in Kwalempona irrigation scheme, $\mathrm{Ca}^{2+}$ is not limiting in the rest of the surveyed MUs as the values lies above the proposed critical limits.

\subsubsection{Exchangeable Magnesium}

Exchangeable $\mathrm{Mg}^{2+}$ range from $0.9 \mathrm{cmol}(+) \mathrm{kg}^{-1}-6.2$ cmol $(+) \mathrm{kg}^{-1}$. This was rated as medium in $42 \%$, high in $47 \%$ and very high in $11 \%$ of the study MUs. The recommended value of $\mathrm{Mg}^{2+}$ in most crops is $2 \mathrm{cmol}(+) \mathrm{kg}^{-1}$ [47]. These data suggests that $56 \%$ of all the surveyed MUs in ERPP irrigation schemes in Pemba and Unguja have sufficient $\mathrm{Mg}^{2+}$ supplies for crop growth whereas the other $31 \%$ have insufficient $\mathrm{Mg}$. 


\subsubsection{Exchangeable Potassium}

Potassium $(\mathrm{K})$ in the surveyed area range from $0.06 \mathrm{cmol}$ (+) $\mathrm{kg}^{-1}$ to $0.52 \mathrm{cmol}(+) \mathrm{kg}^{-1}$ rated as very low in $16 \%$, low in $26 \%$ and medium in $58 \%$ the studied MUs. In general terms, a response to $\mathrm{K}$ fertilizers is likely when a soil has an exchangeable $\mathrm{K}$ value of $<0.2 \mathrm{cmol}(+) \mathrm{kg}^{-1}$ soil and unlikely when it is above $0.4 \mathrm{cmol}(+) \mathrm{kg}^{-1}$ soil $[36 ; 48]$. In this survey, $42 \%$ are likely to respond to $\mathrm{K}$ fertilizers, $28 \%$ are unlikely whereas $46 \%$ will somehow respond to $\mathrm{K}$ fertilisers since they are in between. The data shows that there are sufficient levels of $\mathrm{K}$ in $28 \%$ of the MUs surveyed in the ERPP irrigation schemes in Pemba and Unguja, and so, $\mathrm{K}$ is unlikely to respond if applied.

Table 4. Soil Fertility Data Interpretation for ERPP Irrigation schemes in Pemba and Unguja Islands (0 - $30 \mathrm{~cm})$.

\begin{tabular}{|c|c|c|c|c|c|c|c|c|c|c|c|c|c|c|c|}
\hline \multirow{2}{*}{ Scheme } & \multirow{2}{*}{$\mathbf{R P}$} & \multirow{2}{*}{$\begin{array}{l}\text { Soil fertility } \\
\text { Unit symbol } \\
\end{array}$} & \multirow{2}{*}{$\begin{array}{l}\text { Land form } \\
\text { characteristics }\end{array}$} & \multirow{2}{*}{ S (\%) } & \multirow{2}{*}{$\begin{array}{l}\mathrm{pH} \\
\left(\mathrm{H}_{2} \mathrm{O}\right)\end{array}$} & \multicolumn{10}{|c|}{ Soil fertility rating } \\
\hline & & & & & & $\mathbf{N}$ & $\mathbf{P}$ & $\mathbf{K}$ & $\mathbf{C a}$ & Mg & $\mathbf{N a}$ & $\% \mathrm{OC}$ & CEC & ESP & $\mathbf{C} / \mathbf{N}$ \\
\hline \multicolumn{16}{|l|}{ PEMBA } \\
\hline \multirow[t]{3}{*}{ Dobi } & DB-MP2 & Va11 & Almost flat & $<2$ & SLA & VL & $\mathrm{L}$ & VL & VH & M & M & $\mathrm{L}$ & M & NS & PQ \\
\hline & DB-P1 & Va12 & Almost flat & $<1$ & MA & VL & $\mathrm{L}$ & VL & $\mathrm{H}$ & M & M & $\mathrm{L}$ & $\mathrm{H}$ & NS & MQ \\
\hline & DB-MP1 & Hil & Sloping & $<2$ & SA & VL & $\mathrm{L}$ & VL & $\mathrm{VH}$ & $\mathrm{H}$ & M & $\mathrm{L}$ & $\mathrm{H}$ & NS & PQ \\
\hline \multirow[t]{2}{*}{ Kwalempona } & KWA-MP2 & Val & Almost flat & $<2$ & MA & VL & $\mathrm{L}$ & $\mathrm{L}$ & VH & $\mathrm{H}$ & M & M & $\mathrm{VH}$ & NS & PQ \\
\hline & KWA-MP1 & Hil & Sloping & $2-3$ & MA & VL & $\mathrm{L}$ & $\mathrm{L}$ & VH & $\mathrm{H}$ & M & M & VH & NS & PQ \\
\hline \multirow[t]{3}{*}{ Machigini } & MA-P1 & Val & Almost flat & $<2$ & SA & VL & $\mathrm{L}$ & M & $\mathrm{VH}$ & $\mathrm{VH}$ & M & M & $\mathrm{VH}$ & NS & PQ \\
\hline & MA-MP2 & $\mathrm{Va} 2$ & Almost flat & $<2$ & MA & VL & $\mathrm{L}$ & M & $\mathrm{H}$ & M & M & M & $\mathrm{M}$ & NS & PQ \\
\hline & MA-MP1 & Hi1 & Sloping & $2-3$ & SA & VL & $\mathrm{L}$ & M & $\mathrm{VH}$ & $\mathrm{H}$ & M & $\mathrm{H}$ & $\mathrm{VH}$ & NS & PQ \\
\hline Ole & OLE-P1 & $\mathrm{Pa} 1$ & Almost flat & $0-1$ & MA & VL & M & M & $\mathrm{VH}$ & $\mathrm{H}$ & M & M & $\mathrm{VH}$ & NS & PQ \\
\hline \multicolumn{16}{|l|}{ UNGUJA } \\
\hline K/Mzungu & KBM-P1 & $\mathrm{Pa} 2$ & Almost flat & $<2$ & MA & VL & M & M & VH & $\mathrm{H}$ & M & $\mathrm{H}$ & $\mathrm{H}$ & NS & PQ \\
\hline \multirow[t]{3}{*}{ Bandamaji } & BM-P1 & $\mathrm{Pa} 1$ & Almost flat & $<2$ & $\mathrm{~N}$ & VL & $\mathrm{L}$ & M & $\mathrm{VH}$ & M & M & M & M & NS & PQ \\
\hline & BM-MP2 & $\mathrm{Pa} 2$ & Almost flat & $<2$ & MA & VL & $\mathrm{L}$ & $\mathrm{L}$ & VH & M & $\mathrm{H}$ & M & $\mathrm{H}$ & NS & PQ \\
\hline & BM-MP1 & $\mathrm{Pa} 3$ & Almost flat & $<2$ & SLA & VL & $\mathrm{L}$ & M & $\mathrm{VH}$ & $\mathrm{VH}$ & M & M & $\mathrm{VH}$ & NS & PQ \\
\hline Koani & KN-P1 & $\mathrm{Pa} 1$ & Almost flat & $<2$ & MA & VL & $\mathrm{L}$ & M & VH & $\mathrm{H}$ & $\mathrm{L}$ & M & $\mathrm{VH}$ & NS & MQ \\
\hline \multirow[t]{2}{*}{ Mchangani } & MCH-P1 & $\mathrm{Pa} 1$ & Almost flat & $<2$ & SA & $\mathrm{L}$ & M & $\mathrm{L}$ & VH & M & M & $\mathrm{H}$ & $\mathrm{M}$ & NS & PQ \\
\hline & MCH-P2 & $\mathrm{Pa} 2$ & Almost flat & $<2$ & VSA & $\mathrm{L}$ & $\mathrm{L}$ & M & VH & $\mathrm{H}$ & M & $\mathrm{H}$ & VH & NS & PQ \\
\hline Mtwango & MTW-P2 & $\mathrm{Pa} 1$ & Almost flat & $<2$ & MA & VL & $\mathrm{L}$ & M & $\mathrm{VH}$ & $\mathrm{H}$ & M & M & M & NS & PQ \\
\hline
\end{tabular}

Classification: According to NSS (1990) guidelines. Pa = Plain; Pi = Piedmont; $\mathrm{S}(\%)=$ Slope per cent; $\mathrm{S}=\mathrm{Slope}, \mathrm{N}=\mathrm{Nitrogen}, \mathrm{P}=\mathrm{Phosphorus,} \mathrm{K}=$ Potassium, $\mathrm{Ca}=$ Calcium, $\mathrm{Mg}=$ Magnesium, $\% \mathrm{OC}=$ Per cent organic carbon, $\mathrm{CEC}=$ Cation exchange capacity, ESP $=\mathrm{Exchangeable} \mathrm{sodium} \mathrm{percentage,} \mathrm{C} / \mathrm{N}$ = Carbon to Nitrogen ratio: (Based on Mlingano National Soil Service (NSS, 1990) Laboratory guide to general soil fertility evaluation); VL = Very low; L = Low; $\mathrm{M}=$ Medium; $\mathrm{H}=$ High; $\mathrm{VH}=$ Very high; $\mathrm{NS}=$ Non Sodic; $\mathrm{PQ}=$ Poor quality; $\mathrm{MQ}=$ Moderate quality; $\mathrm{N}=\mathrm{Neutral}$ soil reaction; $\mathrm{SA}=\mathrm{Strong}$ acid; VSA $=$ Very strongly acid, MA $=$ Medium acid, SLA $=$ Slightly acid

\subsection{Cation Exchange Capacity}

Cation exchange capacity (CEC) is the capacity of a soil for ion exchange of positively charged ions between the soil and the soil solution. Cation exchange capacity is used as a measure of fertility, nutrient retention capacity, and the capacity to protect groundwater from cation contamination [49]. The higher the CEC, the more capable the soil is to retain nutrients. High CEC means more nutrients are held on the soil, decreasing their mobility and uptake whereas low CEC means that more nutrients are in the soil solution, making them available to plants but also increasing the likelihood of leaching. Studies have shown that soils with CEC values of between $6-12 \mathrm{cmol}(+) \mathrm{kg}^{-1}$ soil are poor in exchangeable bases [37]. Cation exchange capacity values in most topsoil in the ERPP irrigation schemes in Pemba and Unguja was rated as medium, high to very high (Tables 2, 3 and 4). In all, these values range between $11.5 \mathrm{cmol}(+) \mathrm{kg}^{-1}$ $-71.8 \mathrm{cmol}(+) \mathrm{kg}^{-1}$, and were rated as medium in $32 \%$, high in $16 \%$ and very high in $53 \%$ of the MUs surveyed. The medium to very high CEC could be related to the clay mineral and SOM or OC present in these soils. However, it is recommended to apply both manure/compost manure and the required amount of fertilizer so as to increase the humus content of the soil and consequently, higher or maintenance of higher CEC, thus, better nutrients retention.

\subsection{Exchangeable Sodium (Na) or Exchangeable Sodium Percentage (ESP)}

Tables 2, 3 and 4, presents the levels of topsoil exchangeable $\mathrm{Na}$ and or exchangeable sodium percentage (ESP) as well as the electrical conductivity (EC) in the ERPP irrigation schemes in Pemba and Unguja surveyed MUs. The results of $\mathrm{Na}_{\text {exch }}$ indicates that the levels of $\mathrm{Na}^{+}$in the top soils corresponds to $0.23-1.08 \mathrm{cmol}(+) \mathrm{kg}^{-1}$ soil in the surveyed MUs. These values were rated as low in 5.5\%, medium in $89 \%$ and high in $5.5 \%$ of the surveyed MUs. The corresponding ESP range from $0.4-3.3 \%$. These were rated as non-sodic. The critical values of ESP above which most crops are affected are established at 15\% [50]. These results suggest that the surveyed areas have no threat to sodicity problems. 


\subsection{Cation Ratios}

The availability of nutrients for uptake by plants depends not only upon absolute levels but also on relative amounts of individual elements. The $\mathrm{Ca} / \mathrm{Mg}$ and $\mathrm{Mg} / \mathrm{K}$ ratios indicate if there are imbalances among these nutrients. For example, if the $\mathrm{Ca} / \mathrm{Mg}$ ratio is high, the $\mathrm{Ca}$ will reduce plant uptake of $\mathrm{Mg}$ even if there is enough $\mathrm{Mg}$ in the soil. However, if the ratio is good, but the total amounts of both nutrients are low, they must be applied. It was suggested by some soil chemists working in tropical areas that the optimal cation ratio for the growth of most crops is assumed to be equal to 76/18/6 for $\mathrm{Ca} / \mathrm{Mg} / \mathrm{K}$ respectively (12.7/3/1). Although the general trend doesn't indicate a good balance, more importantly are the individual nutrient ratios i.e. $\mathrm{Ca} / \mathrm{Mg} ; \mathrm{Mg} / \mathrm{K}$; $\mathrm{K} / \mathrm{TEB}$. Research has indicated that the $\mathrm{Ca} / \mathrm{Mg}$ ratios of $3-5$ in the topsoil are considered optimal for most crops. Results of nutrient balance in ERPP irrigation schemes in Pemba and Unguja top soils are shown in Table 5. The data show that $\mathrm{Ca} / \mathrm{Mg}$ ratios ranged from $2.3-12.9, \mathrm{Mg} / \mathrm{K}$ from $3.4-37.2$ and $\mathrm{K} / \mathrm{TEB}$ ratio from $0.4-5.1 \%$. It was observed that $\mathrm{Ca} / \mathrm{Mg}$ ratio in $58 \%$ of the MUs is optimal for most crops and $42 \%$ are un-optimal. The optimal range of $\mathrm{Mg} / \mathrm{K}$ ratio is between $1-4$ for most crops [36]. According to the suggested range, the $\mathrm{K} / \mathrm{Mg}$ ratio is sub optimal. The $\mathrm{K} / \mathrm{TEB}$ is measure of $\mathrm{K}$ deficiency. When this ratio is greater than 2 suggests no $\mathrm{K}$ problems and when less than 2 suggests $\mathrm{K}$ deficiency problems. Results show that $58 \%$ of the surveyed MUs has $\mathrm{K} / \mathrm{TEB}$ ratio $<2 \%$ suggesting $\mathrm{K}$ problems and application of $\mathrm{K}$ is likely to respond. However, $42 \%$ of the surveyed mapping units have K/TEB ratio greater than $2 \%$ suggesting that problems of $\mathrm{K}$ - deficiency is unlikely.

Table 5. Summary of results with emphasis on the nutrient balance in ERPP Irrigation schemes in Pemba and Unguja Islands $(0-30 \mathrm{~cm})$.

\begin{tabular}{|c|c|c|c|c|c|}
\hline Mapping Unit & Texture & $\mathrm{Ca} / \mathbf{M g}$ & $\mathrm{Mg} / \mathrm{K}$ & K/TEB & TEB \\
\hline \multicolumn{6}{|c|}{ Dobi Irrigation Scheme } \\
\hline D-Va11 & SCL & $3.6 \mathrm{~b}$ & $28.7 \mathrm{~b}$ & $0.7 \mathrm{~b}$ & $10.0 \mathrm{~b}$ \\
\hline D-Va12 & $\mathrm{SC}$ & $5.1 \mathrm{a}$ & $37.2 \mathrm{a}$ & $0.4 \mathrm{c}$ & $14.2 \mathrm{a}$ \\
\hline D-Hil & SCL & $2.4 \mathrm{c}$ & $13.7 \mathrm{c}$ & $2.0 \mathrm{a}$ & $9.6 \mathrm{~b}$ \\
\hline \multicolumn{6}{|c|}{ One Way ANOVA (F-Statistics) } \\
\hline F Value & & $920.5^{* * *}$ & $1330.0^{* * *}$ & $3500.0^{* * *}$ & $371.0^{* * *}$ \\
\hline CV $(\%)$ & & 4 & 11 & 2 & 7 \\
\hline \multicolumn{6}{|l|}{ Kwalempona } \\
\hline KWA-Va1 & $\mathrm{C}$ & $7.6 \mathrm{a}$ & $18.7 \mathrm{a}$ & $0.6 \mathrm{c}$ & $28.6 \mathrm{a}$ \\
\hline KWA-Va2 & $\mathrm{C}$ & $4.5 \mathrm{~b}$ & $6.6 \mathrm{c}$ & $2.5 \mathrm{a}$ & $5.7 \mathrm{c}$ \\
\hline KWA-Hi1 & SCL & $2.9 \mathrm{c}$ & $15.2 \mathrm{~b}$ & $1.6 \mathrm{~b}$ & $9.0 \mathrm{~b}$ \\
\hline \multicolumn{6}{|c|}{ One Way ANOVA (F-Statistics) } \\
\hline F Value & & $1486.6^{* * *}$ & $1397.3 * * *$ & $2216.5^{* * *}$ & $3701.7^{* * *}$ \\
\hline CV $(\%)$ & & 5 & 8 & 3 & 9 \\
\hline \multicolumn{6}{|c|}{ Machigini Irrigation Scheme } \\
\hline MA-Va1 & $\mathrm{C}$ & $3.1 \mathrm{~b}$ & $21.1 \mathrm{a}$ & $1.1 \mathrm{c}$ & $26.3 \mathrm{a}$ \\
\hline MA-Va2 & SCL & $2.7 \mathrm{c}$ & $6.0 \mathrm{c}$ & $4.0 \mathrm{a}$ & $8.3 \mathrm{c}$ \\
\hline MA-Hil & SCL & $3.5 \mathrm{a}$ & $7.2 b$ & $3.0 \mathrm{~b}$ & $17.0 \mathrm{~b}$ \\
\hline \multicolumn{6}{|c|}{ One Way ANOVA (F-Statistics) } \\
\hline F Value & & $123.5^{* * *}$ & $2973.4 * * *$ & $1862.8^{* * *}$ & $1737.1 * * *$ \\
\hline CV $(\%)$ & & 4 & 8 & 4 & 9 \\
\hline \multicolumn{6}{|c|}{ Ole Irrigation scheme } \\
\hline $\mathrm{O}-\mathrm{Pa} 1$ & $\mathrm{C}$ & $8.6 \mathrm{~b}$ & $5.5 \mathrm{~b}$ & $1.8 \mathrm{a}$ & $24.1 \mathrm{a}$ \\
\hline $\mathrm{O}-\mathrm{Pa} 2$ & SCL & $9.6 \mathrm{a}$ & $8.6 \mathrm{a}$ & $1.1 \mathrm{~b}$ & $21.1 \mathrm{~b}$ \\
\hline \multicolumn{6}{|c|}{ One Way ANOVA (F-Statistics) } \\
\hline F-Value & & $45.2 * *$ & $691.6 * * *$ & $825.8 * * *$ & $65.8^{* *}$ \\
\hline CV $(\%)$ & & 6 & 5 & 2 & 10 \\
\hline \multicolumn{6}{|l|}{ UNGUJA } \\
\hline \multicolumn{6}{|c|}{ Bandamaji Irrigation scheme } \\
\hline BM-Pa1 & $\mathrm{SC}$ & $4.9 \mathrm{~b}$ & $3.4 \mathrm{c}$ & $4.5 \mathrm{a}$ & $7.7 \mathrm{c}$ \\
\hline BM-Pa2 & SCL & $12.9 \mathrm{a}$ & $11.7 \mathrm{a}$ & $0.6 \mathrm{c}$ & $18.3 \mathrm{~b}$ \\
\hline BM-Pa3 & SCL & $3.3 \mathrm{c}$ & $10.8 \mathrm{~b}$ & $2.1 \mathrm{~b}$ & $21.4 \mathrm{a}$ \\
\hline \multicolumn{6}{|c|}{ One Way ANOVA (F-Statistics) } \\
\hline F-Value & & $2953.1 * * *$ & $1760.6^{* * *}$ & $3480.2 * * *$ & $1362.7 * * *$ \\
\hline CV $(\%)$ & & 6 & 6 & 4 & 8 \\
\hline \multicolumn{6}{|c|}{ Mchangani Irrigation scheme } \\
\hline $\mathrm{MCH}-\mathrm{Pal}$ & SCL & $6.2 \mathrm{~b}$ & $0.0 \mathrm{~b}$ & $1.3 \mathrm{a}$ & $11.2 \mathrm{~b}$ \\
\hline MCH-Pa2 & CL & $10.3 \mathrm{a}$ & $12.8 \mathrm{a}$ & $0.7 \mathrm{~b}$ & $34.6 \mathrm{a}$ \\
\hline \multicolumn{6}{|c|}{ One Way ANOVA (F-Statistics) } \\
\hline F-Value & & $852.44 * * *$ & $4500.0^{* * *}$ & $1238.5^{* * *}$ & $3105.0^{* * *}$ \\
\hline CV $(\%)$ & & 6 & 8 & 2 & 10 \\
\hline
\end{tabular}

***: significant at $P=.001 ; \mathrm{CV}$ : Coefficient of variation. Values followed by dissimilar letters in the same column for each parameter are significantly different from each other at $P=.05$ according to Fischer Least significance difference (LSD). $\mathrm{K}=$ Potassium; $\mathrm{Ca}=\mathrm{Calcium} ; \mathrm{Mg}=\mathrm{Magnesium} ; \mathrm{Na}=\mathrm{Sodium}, \mathrm{TEB}=$ Total Exchangeable Bases, $\mathrm{BS}=$ Base Saturation; $\mathrm{SCL}=$ Sand Clay Loam; $\mathrm{SL}=$ Sand loam; $\mathrm{CL}=$ Clay Loam; $\mathrm{C}=\mathrm{Clay}$. 


\section{Conclusion}

In conclusion, the results of the present study provide soil fertility status in the selected ERPP irrigation schemes. Data also suggest that soil chemical indicators such as $\mathrm{pH}, \mathrm{TN}, \mathrm{P}$ and $\mathrm{OM}$ are the major soil fertility constraints to crop production in the area followed by CEC. This information could be incorporated in the soil fertility management in Tanzania, thus, contributing significantly in the efficient utilisation of land resources in the study areas.

\section{Conflict of Interest}

All the authors do not have any possible conflicts of interest.

\section{References}

[1] OCGS (2007). Office of Chief Government Statistician.

[2] FAO and WWC (2015). Towards a Water and Food Secure Future Critical Perspectives for Policy-makers.

[3] Mutiro, J. \& J. Lautze (2015). Irrigation in Southern Africa: Success or failure? Irrigation and Drainage 64, 157-298.

[4] Ngailo, J. A., J. M. Wickama, A. S. Nyaki and A. L. Kaswamila (1999). Nutrient flow analysis for selected farming systems in the Northern Tanzania: The case of Mbulu, Moshi Rural and Lushoto Districts (pp 49-64). In: Soil and Nutrient management in sub-Saharan Africa in support of the soil fertility initiative. Pp. 376.

[5] Makoi, J. H. J. R. and P. A. Ndakidemi (2007). Reclamation of sodic soils in northern Tanzania, using locally available organic and inorganic resources. African Journal of Biotechnology. 16(6), 1926 - 1931.

[6] Mokwunye, A. U., de Jager A, and Smaling, E. M. A. (1996). Restoring and maintaining the productivity of West African soils: Key to sustainable development. Misc. fertilizer stud 14, Int. Dev. Central Africa, Lome, Togo.

[7] Sanchez, P. A. (2002). Soil fertility and hunger in Africa. Science. 295, 2019-2020.

[8] Mowo, J. G., B. H. Janssen, O., Oenema L. A., German Mrema, J. P., Shemdoe, R. S. (2006). Soil fertility evaluation and management by smallholder farmer communities in northern Tanzania. Agriculture, Ecosystem \& Environment. $116(1-2), 47-59$.

[9] RLDC (2009). Rural Livelihood Development Company, Rice Sector Strategy: Improving rice profitability through increased productivity and better marketing focusing on Tanzania's Central Corridor, Pp 34; November.

[10] NSCA (2012). National Sample Census of Agriculture Small Holder Agriculture Volume II: Crop Sector - National Report (2007/2008).

[11] Scoones, I (2001). Dynamics and Diversity: Soil Fertility and Farming Livelihoods in Africa: Case Studies from Ethiopia, Mali, and Zimbambwe, Earthscan Publications Ltd., London, pp 244.
[12] Hellin, J. (2003). From soil erosion to soil quality. LEISA Mag. Low External Input Sustain Agric. 19 (4).

[13] Ndakidemi, P. A., and J. M. R. Semoka (2006). Soil fertility in Western Usambara Mountains, Northern Tanzania. Pedosphere. 16(2), 237-244.

[14] Defoer, T., Budelman, A (Eds.). Managing Soil Fertility in the Tropics. A Resource Guide for Participatory Learning and Action Research. KIT Publishers, Amsterdam; 2000.

[15] Lyamchai, C. J., J. G. Mowo, J. M. Wickama (2004). Managing new working relationships: partnership and networking. In: AHI Regional Conference, Nairobi.

[16] Ouédraogo, E. (2004). Soil quality improvement for crop production in semi-arid West Africa. $\mathrm{PhD}$ Thesis, Wageningen University, Wageningen.

[17] Saïdou, A., T. W. Kuyper, D. K. Kossou, R. Tossou, P. Richards (2004). Sustainable soil fertility management in Benin: learning from farmers. NJAS-Wageningen. Journal of Life Sciences. 52, 349-369.

[18] Monreal, C. M., H. Dinel, M. Schnitzer, D. S. Gamble, V. O. Biederbeck (1997). Impact of carbon sequestration on functional indicators of soil quality as influenced by management in sustainable agriculture. P. 435-457. In: Lal R et al. (eds.) Soil processes and the carbon cycle, Lewis Publ., CRC Press, Roca balton, FL.

[19] Brady, N. C., R. R. Weil (2002). Nature and Properties of Soils. 13th Edition. With permission of Pearson Education, Inc., Upper Saddle River, New Jersey.

[20] Muchena, F. M. and R. M. Kiome (1995). The role of soil science in agricultural development in East Africa. Geoderma. 67; 141-157.

[21] Makoi J. H. J. R (2003). Soil Fertility assessment for irrigation in the selected schemes of Mbulu District. In: United Republic of Tanzania, Ministry of Agriculture and Food Security, Participatory Irrigation Development Programme. ZITS, Moshi, Kilimanjaro.

[22] Day, P. R. (1965). Particle fraction and particle size analysis. In: Black CA et al. (Eds). Methods of soil analysis. Part 2. American Society of Agronomy, Madison. Pp. 545-567.

[23] United State Department of Agriculture, (1975). Soil Taxonomy. A basic system of soil classification for making and interpreting soil surveys. Agricultural Handbook No. 436. Washington D. C. pp. 754.

[24] Allison, E (1965). Organic carbom. In: Black CA et al. (eds). Methods of soil analysis. Part 2. American Society of Agronomy, Madison. Pp. 1367-1378.

[25] Walkley, A., A. Black (1934). Determination of organic matter. Soil Sci. 37:29-38.

[26] Peech, M. (1965). Hydrogen ion activity. In: Black CA et al. (Eds). Methods of soil analysis. Part 2. American Society of Agronomy, Madison. Pp. 914-926.

[27] Bremner, J. M. (1965). Total nitrogen. In: Black CA et al. (eds). Methods of soil analysis. Part 2. American Society of Agronomy, Madison. Pp. 1149-1178.

[28] Chapman, H. D. (1965). Cation exchange capacity. In: Black CA et al. (Eds). Methods of soil analysis. Part 2. American Society of Agronomy, Madison. Pp. 891-901. 
[29] Polemio, M. J. D. Rhoades (1977). Determining cation exchange capacity: A new procedure for calcareous and gypsiferous soils. Soil Science Society of American Journal. 41, 524-528.

[30] Hesse, P. R. (1971). A Text Book of Soil Chemistry Analysis. John Murray Ltd. London. Pp. 120-309.

[31] Piper, C. S. (1942). Soil and Plant Analysis. University of Adelaide.

[32] Rodriguez, J. B., J. R. Self and N. P. Soltanpour (1994). Optimal conditions for phosphorous analysis by the ascorbic acid-molybdenum blue method. Soil Science Society of American Journal. 58, 866-870.

[33] Murphy, J., and J. P. Riley. (1962). A modified single solution method for determination of phosphates in natural waters. Analytica Chimica Acta. 27, 31-36.

[34] Page, A. L., R. H., Miller, D. R. Keeney eds. (1982). Methods of Soil Analysis, Part 2: Chemical and Microbiological Properties, 2nd ed.: American Society of Agronomy, Madison, WI.

[35] Steel, R. G. D., J. H. Torrie (1980). Principles and procedures of statistics: A biometrical approach, Second Edition. McGraw Hill, New York.

[36] NSS (1990). Laboratory procedures for routine soil analysis, 3rd ed. Ministry of Agriculture and Livestock Development, National Soil Service (NSS), ARI, Mlingano.

[37] Foy, C. D. (1992). Soil chemical factors limiting plant root growth. Adv Soil Sci. 19:97-131.

[38] Elisa, A. A., J. Shamshuddin, CI. Fauziah (2011). Root elongation, root surface area and organic acid exudation by rice seedling under $\mathrm{Al} 3+$ and/or $\mathrm{H}+$ stress. Amer J Agric Bio Sci. 6: 324-331.

[39] Prasad, R and J. F. Power (1997). Soil Fertility Management for Sustainable Agriculture. Lewis Publishers, New York, NY. $356 \mathrm{pp}$.

[40] Loveland, P., J. Webb (2003). Is there a critical level of organic matter in the agricultural soils of temperate regions: a review. Soil and Tillage Research, 70: 1-18.

[41] Makoi J. H. J. R., P. A. Ndakidemi (2008). Selected soil enzymes: examples of their potential roles in the ecosystem. African Journal of Biotechnology 7; 181-191.

[42] Vermeer, J. G., F. Berendse (1983). The relationship between nutrient availability, shoot biomass and species richness in grassland and wetland communities. Vegetation. 53; 121-126.

[43] Tilman, G. D. (1984). Plant dominance along an experimental nutrient gradient. Ecol. 65; 1445-1453.

[44] Facelli, J. M., S. T. A. Pickett (1991). Plant litter. Its dynamics and effects on plant community structure. Bot Rev. 57:1-32.

[45] Marx, E. S., J. M. Hart \& R. G. Stevens (1996). Soil test interpretation guide. Oregon State University Extension Service Oregon, USA.

[46] Smiciklas, K. D., R. E. Mullen, R. E. Carlson, A. D. Knapp (1989). Drought-induced stress effect on soybean seed calcium and quality. Crop Science 29; 1519-1523.

[47] Schwartz, H. F., M. A. Coralles (1989). Nutritional disorders in beans. In: Schwartz HF, Coralles MAP (Eds.) Bean production Problems in the tropics. Second edition. International Centre for Tropical Agriculture (CIAT), Cali. Pp. 75-604.

[48] Anderson, G. D. (1973). Potassium responses of various crops in East Africa. In: Proceedings of the 10th Colloquium of the International Potash Potash Insititute, Abijan, Ivory Coast. International Potash Insititute, Abijan. Pp. 413-437.

[49] Peverill, K. I., L. A. Sparrow and D. J. Reuter (1999). Soil Analysis: An Interpretation Manual CSIRO, Collingwood, Australia, pp. 170- 174.

[50] Lebron, I., D. L. Suarez, T. Yoshida (2002). Gypsum effect on the aggregate size and geometry of three sodic soils under reclamation. Soil Science Society of American Journal 66; 9298 . 